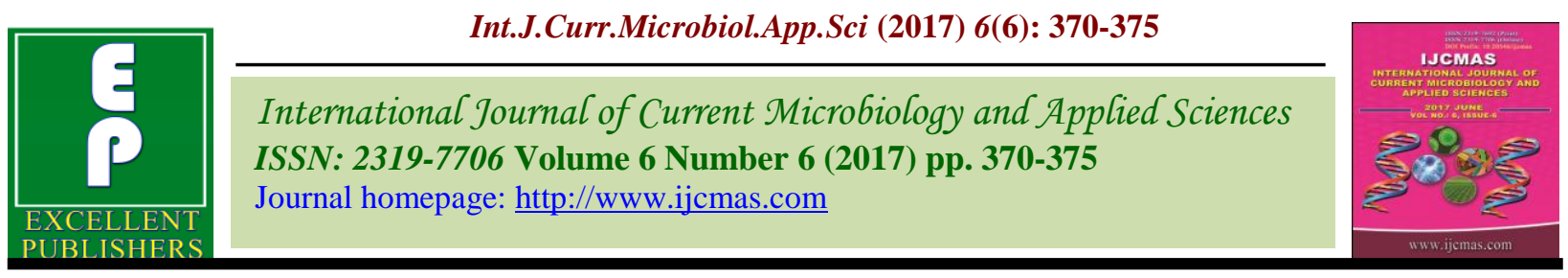

Original Research Article

https://doi.org/10.20546/ijcmas.2017.606.043

\title{
Thifluzamide 24\% SC: A New Molecule for Potato Tubers Treatment against Black Scurf Disease of Potato Caused by Rhizoctonia solani
}

\author{
Mehi Lal $^{1 *}$, Sanjeev Sharma ${ }^{2}$, S. K. Chakrabarti ${ }^{2}$ and Manoj Kumar ${ }^{1}$ \\ ${ }^{1}$ ICAR-Central Potato Research Institute Campus, Modipuram 250 110, \\ Uttar Pradesh, India \\ ${ }^{2}$ ICAR-Central Potato Research Institute, Shimla 171 001, Himachal Pradesh, India \\ *Corresponding author
}

\begin{tabular}{|c|c|}
\hline & A B S T R A C T \\
\hline & $\begin{array}{l}\text { Black scurf of potato caused by Rhizoctonia solani is one of the most important } \\
\text { disease in the category of soil and tuber borne disease especially in fungal group. }\end{array}$ \\
\hline Keywords & $\begin{array}{l}\text { Infested seed tubers are the main source of infection. Boric acid and pencycuron } \\
\text { are the two chemicals which are frequently used by the Indian farmers to control }\end{array}$ \\
\hline $\begin{array}{l}\text { Black scruf, } \\
\text { Disease severity, } \\
\text { Potato, } \\
\text { Rhizoctonia Solani, } \\
\text { Thifluzamide } 24 \% \\
\text { SC. } \\
\end{array}$ & $\begin{array}{l}\text { black scurf of potato. New molecule: Thifluzamide } 24 \% \text { SC was evaluated for bio- } \\
\text { efficacy and phytotoxicity effect against black scurf disease of potato during two } \\
\text { consecutive years (2014-2016). Results revealed that Thifluzamide } 24 \% \text { SC @ } 3.0 \\
\mathrm{ml} / 10 \mathrm{~kg} \text { seed was highly effective and resulted in reduction in disease incidence } \\
(95.69 \% \text { during } 2014-15 \text { and } 96.50 \% \text { during } 2015-16) \text { and disease severity }\end{array}$ \\
\hline Article Info & $\begin{array}{l}\text { (97.39\% during } 2014-15 \text { and } 97.43 \% \text { during } 2015-16) \text { with higher yield ( } 42.93 \\
\text { tha) followed by Carboxin } 37.5+\text { Thiram } 37.5 \text { WS @ } 25 \mathrm{~g} / 10 \mathrm{~kg} \text { tubers. The plant }\end{array}$ \\
\hline $\begin{array}{l}\text { Accepted: } \\
\text { 04 May } 2017 \\
\text { Available Online: } \\
\text { 10 June } 2017\end{array}$ & $\begin{array}{l}\text { emergence percentage ranged from } 90.22 \text { to } 97.39 \% \text { at tested different doses of } \\
\text { Thifluzamide } 24 \% \text { SC. No adverse effect on emergence (\%) and on phytotoxicity } \\
\text { parameters was observed when Thifluzamide } 24 \% \text { SC was tested at } 2.5 \mathrm{ml} / 10 \mathrm{~kg}\end{array}$ \\
\hline & $\begin{array}{l}\text { tubers. Thifluzamide } 24 \% \text { SC @ } 2.0,2.5 \text { and } 3.0 \mathrm{ml} / 10 \mathrm{~kg} \text { seed tubers was } \\
\text { effective against black scurf of potato by slurry treatment. }\end{array}$ \\
\hline
\end{tabular}

\section{Introduction}

Black scurf of potato caused by the fungus Rhizoctonia Solani Kuhn (teleomorph Thanatephorus cucumeris [A.B. Frank] Donk) is a serious disease of potato in India and worldwide. It causes $10-25 \%$ yield loss in India depending upon growing regions potatoes i.e. hills and plain (Sharma, 2015), whereas up to $30 \%$ yield loss reported in Canada (Banville, 1989; Wood hall et al., 2008), besides it also decreases the market acceptability by the consumers due to black sclerotial present on surface of the tubers. The characteristic symptoms of black scurf viz., dark brown to black colored hard masses of sclerotia, irregularly shaped and superficial, varying from small, flat on tubers with tightly adhere and stem canker are the result of Rhizoctonia disease complex in potato (Tsror, 2010). The $R$. solani may also attack and kill emerging sprouts in soil and results in reduced crop stand and thus cause more loss in yield (Lakra, 1992). Now days, sclerotial structure is also observed on roots of potato plants, besides surface of potato tubers. Black 
scurf is distributed in India in different regions at different levels of severity and is a major disease problem in fields where potato is cultivated year after year in the same field (Khurana et al., 1998; Arora, 2012). Control measures through cultural practices and biological control are used but they are not completely effective and black scurf disease remains a persistent problem. Seed treatment with $3 \%$ boric acid as dip treatment before cold storage has been recommended by Central Potato Research Institute, Shimla, India as a safe and effective chemical treatment for the control of this disease (Anonymous, 1987; Somani, 1988; Singh et al., 2002). The disease is also managed through seed treatment with benomyl, carbendazim, thiabendazole, pencycuron, penflufen 240 FS and Thiophinate methyl 45\%+ pyaclostrobin $5 \%$ FS (Banyal, 2002; Thind et al., 2002; Lal et al., 2014; Lal et al., 2016). Two chemicals viz., Boric acid and Pencycuron are frequently used by Indian farmers to management black scurf of potato (Khurana et al., 2001). Thifluzamide is comes under the chemical group of Thiazolecarboxamides and its target site is Succinate dehydrogease complex II in respiratory chain and affect the fungal respiration (FRAC, 2017). It belongs to code 7 under FRAC. This molecule is registered for use in rice, turf, potatoes, coffee and strawberries in Brazil, Mexico, Colombia, Venezuela, Japan, Korea, China and Vietnam (Kumar et al., 2012). Thifluzamide $24 \% \mathrm{SC}$ is registered on rice but not on potato. Therefore, in the present study a new molecule, Thifluzamide $24 \%$ SC was evaluated for its efficacy against black scurf of potato and phytotoxicity under field conditions.

\section{Materials and Methods}

The field experiments were conducted at ICAR-Central Potato Research Institute Campus, Modipuram, Meerut (29.1o N, 77.92o E, $300 \mathrm{msl}$ ) during 2014-15 and 201516 crop seasons. Cent percent infested diseased seed tubers of cv. Kufri Bahar were used in this experiment. Thifluzamide $24 \%$ SC was evaluated at four doses $(1.5,2.0,2.5$ and $3.0 \mathrm{ml} / 10 \mathrm{~kg}$ tubers) for bio-efficacy and two doses (2.5 and $6.0 \mathrm{ml} / 10 \mathrm{~kg}$ tubers) for phytotoxicity against black scurf of potato. The efficacy was compared with Carbendazim 25\% + Mancozeb 50\% WS @ $7.0 \mathrm{~g} / 10 \mathrm{~kg}$ and Carboxin 37.5 + Thiram 37.5 WS @ $25 \mathrm{~g} / 10 \mathrm{~kg}$ tubers. For each treatment, required water volume (200 ml of water/10 kg tubers) was used for making slurry with desired quantity of fungicides for seed tuber treatment. After treatment, tubers were shade dried before planting. The untreated tubers were kept as standard control. Planting of the experiments were carried out in the mid of November each year. The treated seed tubers were planted at 60 (row-row) x $20 \mathrm{~cm}$ (plant plant) spacing in $3 \times 3 \mathrm{~m}$ plot sizes. Each treatment was replicated three times and planted in Randomized Block Design (RBD). The crop was raised following the standard agronomic practices of the region. Emergence (\%) was recorded at 25 days and 35 days of planting and other phytotoxicity parameters viz, leaf tip injury, chlorosis, necrosis, wilting, hyponasty and epinasty were also recorded (15 plants/replication) at 1, 3, 5, 7, 10 and 15 days after germination (starting from 25 days after planting). Haulms were cut $>100$ days after planting and the crops were harvested 2 weeks after dehaulming. A total of 225 tubers (75 tubers/replication) were taken randomly from each treatment at harvesting for recording disease incidence and severity. Disease severity was calculated on 0-4 scale rating (0- no disease, 1: $1-25 \%$ surface areas covered, 2: 26-50\% surface areas covered, 3: $51-75 \%$ surface areas covered and 4: $>75 \%$ surface area covered). Disease incidence, disease severity, percentage disease control, and tuber yield $(\mathrm{t} / \mathrm{ha})$ were calculated at the time of 
harvesting. The disease index was calculated as per the method of Somani (1986). The experimental data were analyzed with the help of IRRISTAT software (version 4.4.20030719).

\section{Results and Discussion}

The emergence (after 35 days of planting) percentage ranged from 90.22 to $95.11 \%$ including in healthy control during 2014-15 whereas it was 90.22 to $97.78 \%$ during 201516 (Table 1). Both the years' emergence percentage of treated tubers with Thifluzamide $24 \%$ SC was statistically at par with emergence percentage in diseased (untreated) control. The data recorded on efficacy of fungicides revealed that Thifluzamide $24 \%$ SC was effective for control of black scurf (Table 1). The disease incidence was reduced from $92.89 \%$ in diseased (untreated) control to $4.0 \%$ in Thifluzamide $24 \%$ SC @ $3.0 \mathrm{ml} / 10 \mathrm{~kg}$ seed, $5.89 \%$ in Thifluzamide 24\% SC @ $2.5 \mathrm{ml} / 10$ kg seed, $7.56 \%$ in Thifluzamide 24\% SC @ $2.0 \mathrm{ml} / 10 \mathrm{~kg}$ seed, and $4.44 \%$ in Carboxin $37.5+$ Thiram $37.5 \mathrm{WS}$ used @ 25g/10kg seed tubers during crop season 2014-15. These treatments were statistically at par each other's.

Similarly, disease severity was reduced from $38.33 \%$ in diseased (untreated) control to $1.0 \%$ in Thifluzamide 24\% SC @ 3.0 ml/10 $\mathrm{kg}$ seed, 1.89\% in Thifluzamide 24\% SC @ $2.5 \mathrm{ml} / 10 \mathrm{~kg}$ seed, $2.00 \%$ in Thifluzamide 24\% SC @2.0 ml/10 kg seed, and 1.11\% in Carboxin 37.5+Thiram37.5WS used @ $25 \mathrm{~g} / 10 \mathrm{~kg}$ seed. The next best treatment was Thifluzamide 24\% SC @ $1.5 \mathrm{ml} / 10 \mathrm{~kg}$ seed and Carbendazim 25\%+mancozeb50\%WS@ $7 \mathrm{~g} / 10 \mathrm{~kg}$ seed. During the crop season 201516, disease incidence was reduced from $88.89 \%$ in diseased (untreated) control to $3.11 \%$ in Thifluzamide 24\% SC @ 3.0 ml/10 $\mathrm{kg}$ seed, 5.33\% in Thifluzamide 24\% SC @
$2.5 \mathrm{ml} / 10 \mathrm{~kg}$ seed, $6.22 \%$ in Thifluzamide 24\% SC @ $2.0 \mathrm{ml} / 10 \mathrm{~kg}$ seed, and $5.78 \%$ in Carboxin 37.5+Thiram37.5WS used@ $25 \mathrm{~g} / 10 \mathrm{~kg}$ seed tubers. The next best treatments were Thifluzamide 24\% SC @ 1.5 $\mathrm{ml} / 10 \quad \mathrm{~kg}$ seed and Carbendazim 25\%+mancozeb50\% WS @ 7g/10kg seed tubers. Similarly, disease severity was reduced from $51.89 \%$ in diseased (untreated) control to $1.33 \%$ in Thifluzamide 24\% SC @ $3.0 \mathrm{ml} / 10 \mathrm{~kg}$ seed, $2.44 \%$ in Thifluzamide 24\% SC @2.5 ml/10 kg seed, 2.56\% in Thifluzamide 24\% SC @ $2.0 \mathrm{ml} / 10 \mathrm{~kg}$ seed, and $2.52 \%$ in Carboxin 37.5+Thiram37.5WS used@25g/10kg seed.

None of the treatments could produce tuber yield equal to healthy control during 2014-15 and 2015-16. However, Highest tuber yield was recorded in Thifluzamide 24\% SC @ 2.0 $\mathrm{ml} / 10 \mathrm{~kg}$ seed during 2014-15, whereas, during 2015-16 highest tuber yield was recorded in Thifluzamide 24\% SC @ 3.0 $\mathrm{ml} / 10 \mathrm{~kg}$ seed. These are statically at par with other doses of Thifluzamide $24 \%$ SC, Carbendazim 25\%+mancozeb50\% WS @ $7 \mathrm{~g} / 10 \mathrm{~kg}$ seed and Carboxin 37.5+Thiram37.5 WS@25g/10kg seed.

With regard to phytotoxicity, various parameter, viz., leaf tip injury, chlorosis, necrosis, wilting, hyponasty and epinasty was studied with two doses of Thifluzamide $24 \%$ SC @ $2.5 \mathrm{ml}$ and $6.0 \mathrm{ml} / 10 \mathrm{~kg}$ of seed. It was observed that only leaf tip injury was recorded at lower score in the higher dose of Thifluzamide 24\% SC @ $6.0 \mathrm{ml} / 10 \mathrm{~kg}$ of seed. However, no phytotoxicity was observed in treatment Thifluzamide 24\% SC @ $2.5 \mathrm{ml} / 10 \mathrm{~kg}$ of seed (Table 2).

Based on bio-efficacy and phytotoxixcity studies, it can be concluded that Thifluzamide 24\% SC @ 2.0, 2.5, and $3.0 \mathrm{ml} / 10 \mathrm{~kg}$ of seed can be used for managing seed borne infection of $R$. solani. 
Table.1 Bio-efficacy effect of Thifluzamide 24\% SC against black scurf of potato

\begin{tabular}{|c|c|c|c|c|c|c|c|c|c|c|c|c|c|}
\hline \multirow[t]{2}{*}{ Treatments } & \multirow[t]{2}{*}{ Dose $\mathrm{ml}$ or gm/10kg seed } & \multicolumn{6}{|c|}{$2014-15$} & \multicolumn{6}{|c|}{$2015-16$} \\
\hline & & $\begin{array}{l}\text { Emerge } \\
\text { nce }(\%)\end{array}$ & $\begin{array}{c}\text { Disease } \\
\text { inciden } \\
\text { ce }(\%)\end{array}$ & $\begin{array}{c}\text { Disease } \\
\text { severity } \\
(\%)\end{array}$ & $\begin{array}{l}\text { Reducti } \\
\text { on }(\%) \\
\text { in } \\
\text { disease } \\
\text { inciden } \\
\text { ce over } \\
\text { control }\end{array}$ & $\begin{array}{l}\text { Reducti } \\
\text { on }(\%) \\
\text { in } \\
\text { disease } \\
\text { severity } \\
\text { over } \\
\text { control }\end{array}$ & $\begin{array}{l}\text { Yield } \\
\text { (t/ha) }\end{array}$ & $\begin{array}{c}\text { Emergen } \\
\text { ce } \\
(\%)\end{array}$ & $\begin{array}{c}\text { Disease } \\
\text { incidence } \\
(\%)\end{array}$ & $\begin{array}{c}\text { Disease } \\
\text { severity } \\
(\%)\end{array}$ & $\begin{array}{l}\text { Reducti } \\
\text { on }(\%) \\
\text { in } \\
\text { disease } \\
\text { inciden } \\
\text { ce over } \\
\text { control }\end{array}$ & $\begin{array}{l}\text { Reducti } \\
\text { on }(\%) \\
\text { in } \\
\text { disease } \\
\text { severity } \\
\text { over } \\
\text { control }\end{array}$ & $\begin{array}{l}\text { Yield } \\
\text { (t/ha) }\end{array}$ \\
\hline Thifluzamide $24 \%$ SC & $\begin{array}{c}1.5 \mathrm{ml} / 10 \mathrm{~kg}(15 \mathrm{ml} / 100 \\
\mathrm{kg} \text { tubers })\end{array}$ & 92.44 & 10.67 & 3.22 & 88.52 & 91.59 & 28.07 & 90.67 & 9.78 & 5.22 & 89.00 & 89.94 & 39.74 \\
\hline Thifluzamide $24 \%$ SC & $\begin{array}{l}2.0 \mathrm{ml} / 10 \mathrm{Kg}(20 \mathrm{ml} / 100 \\
\mathrm{kg} \text { tubers })\end{array}$ & 95.38 & 7.56 & 2.00 & 91.87 & 94.78 & 32.16 & 97.78 & 6.22 & 2.56 & 93.00 & 95.08 & 42.08 \\
\hline Thifluzamide $24 \%$ SC & $\begin{array}{c}2.5 \mathrm{ml} / 10 \mathrm{~kg}(25 \mathrm{ml} / 100 \\
\mathrm{kg} \text { tubers })\end{array}$ & 90.22 & 5.89 & 1.89 & 93.66 & 95.07 & 29.05 & 90.22 & 5.33 & 2.44 & 94.00 & 95.29 & 41.98 \\
\hline Thifluzamide $24 \%$ SC & $\begin{array}{c}3.0 \mathrm{ml} / 10 \mathrm{~kg}(30 \mathrm{ml} / 100 \\
\mathrm{kg} \text { tubers })\end{array}$ & 93.78 & 4.00 & 1.00 & 95.69 & 97.39 & 31.86 & 92.44 & 3.11 & 1.33 & 96.50 & 97.43 & 42.93 \\
\hline $\begin{array}{c}\text { Carbendazim } 25 \%+\text { mancozeb } \\
50 \% \% \mathrm{WS}\end{array}$ & $\begin{array}{c}7.0 \mathrm{~g} / 10 \mathrm{~kg}(70.0 \mathrm{~g} / 100 \mathrm{Kg} \\
\text { tubers })\end{array}$ & 92.85 & 21.78 & 8.89 & 76.56 & 76.81 & 29.48 & 92.44 & 17.78 & 9.78 & 80.00 & 81.16 & 40.96 \\
\hline $\begin{array}{c}\text { Carboxin37.5+Thiram } 37.5 \\
\text { WS }\end{array}$ & $\begin{array}{c}25.0 \mathrm{~g} / 10 \mathrm{~kg}(250 \mathrm{~g} / 100 \mathrm{~kg} \\
\text { tubers })\end{array}$ & 90.22 & 4.44 & 1.11 & 95.22 & 97.10 & 29.14 & 91.56 & 5.78 & 2.52 & 93.50 & 95.14 & 40.91 \\
\hline Diseased (untreated)-control & $100 \%$ diseased tuber & 93.70 & 92.89 & 38.33 & 0.00 & 0.00 & 26.40 & 92.44 & 88.89 & 51.89 & 0.00 & 0.00 & 38.16 \\
\hline Healthy-control & $100 \%$ healthy tuber & 95.11 & 4.44 & 1.11 & 95.22 & 97.10 & 33.56 & 97.78 & 3.11 & 1.00 & 96.50 & 98.07 & 45.15 \\
\hline $\mathrm{CD}(0.05)$ & & 7.34 & 2.59 & 3.38 & & & 4.31 & 6.53 & 3.33 & 2.25 & & & 3.87 \\
\hline
\end{tabular}

Table.2 Evaluation of Thifluzamide $24 \%$ SC on phytotoxicity parameters (score 0-10)

\begin{tabular}{|c|c|c|c|c|c|c|c|c|c|c|c|c|c|c|c|c|c|c|c|c|c|c|c|c|c|c|c|c|c|c|c|c|c|c|c|c|c|c|c|}
\hline \multirow{3}{*}{$\begin{array}{l}\text { S. } \\
\text { N } \\
\text { o. }\end{array}$} & \multirow{3}{*}{ Treatments } & \multirow{3}{*}{$\begin{array}{c}\text { Formu-lation } \\
(\mathrm{ml} / \mathbf{1 0 k g})\end{array}$} & \multicolumn{6}{|c|}{ Leaf tip injury } & \multicolumn{6}{|c|}{ Chlorosis } & \multicolumn{6}{|c|}{ Necrosis } & \multicolumn{6}{|c|}{ Wilting } & & \multicolumn{6}{|c|}{ Hyponasty } & \multicolumn{6}{|c|}{ Epinasty } \\
\hline & & & \multicolumn{37}{|c|}{ At different days intervals } \\
\hline & & & 1 & 3 & 5 & 7 & $\begin{array}{l}1 \\
0\end{array}$ & $\begin{array}{l}1 \\
5\end{array}$ & $\mathbf{1}$ & 3 & 5 & 7 & $\begin{array}{l}\mathbf{1} \\
\mathbf{0}\end{array}$ & $\begin{array}{l}1 \\
5\end{array}$ & 1 & 3 & 5 & 7 & $\begin{array}{l}1 \\
\mathbf{0}\end{array}$ & $\begin{array}{l}1 \\
5\end{array}$ & 1 & 3 & 5 & 7 & 0 & & & $\mathbf{1}$ & $\mathbf{3}$ & 5 & 7 & $\begin{array}{l}\mathbf{1} \\
\mathbf{0}\end{array}$ & $\begin{array}{l}1 \\
5\end{array}$ & $\mathbf{1}$ & 3 & 5 & 7 & $\begin{array}{l}\mathbf{1} \\
\mathbf{0}\end{array}$ & 15 \\
\hline 1 & $\begin{array}{c}\text { Thifluzamide } \\
24 \% \mathrm{SC}\end{array}$ & $\begin{array}{c}2.5 \mathrm{ml} / 10 \mathrm{~kg} \\
(25 \mathrm{ml} / 100 \mathrm{~kg} \\
\text { tubers })\end{array}$ & 0 & 0 & 0 & 0 & 0 & 0 & 0 & 0 & 0 & 0 & 0 & 0 & 0 & 0 & 0 & 0 & 0 & 0 & 0 & 0 & 0 & 0 & c & & & 0 & 0 & 0 & 0 & 0 & 0 & 0 & & 0 & 0 & 0 & 0 \\
\hline 2 & $\begin{array}{c}\text { Thifluzamide } \\
24 \% \text { SC }\end{array}$ & $\begin{array}{c}6 \mathrm{ml} / 10 \mathrm{Kg} \\
(60 \mathrm{ml} / 100 \mathrm{~kg} \\
\text { tubers })\end{array}$ & 1 & 1 & 1 & 1 & 1 & 1 & 0 & 0 & 0 & 0 & 0 & 0 & 0 & 0 & 0 & 0 & 0 & 0 & 0 & 0 & 0 & 0 & 0 & & & 0 & 0 & 0 & 0 & 0 & 0 & 0 & & 0 & 0 & 0 & 0 \\
\hline 3 & $\begin{array}{c}\text { (Untreated } \\
\text { control }\end{array}$ & - & \begin{tabular}{l|l}
0 \\
\end{tabular} & 0 & 0 & 0 & 0 & 0 & 0 & 0 & 0 & 0 & 0 & 0 & 0 & 0 & 0 & 0 & 0 & 0 & 0 & 0 & 0 & 0 & 0 & & & 0 & 0 & 0 & 0 & 0 & 0 & \begin{tabular}{l|l}
0 \\
\end{tabular} & & 0 & 0 & 0 & 0 \\
\hline
\end{tabular}

Score: Zero- No Phytotoxicity, 1: 0-10\%, 2: 11-20\%, 3:21-30\%, 4:31-40\%, 5:41-50\%, 6:51-60\%, 7:61-70\%, 8:71-80\%, 9:81-90\%, 10:91-100\% 
Rauf et al., (2007) reported that pencycuron was effective for management of black scurf disease of potato, which decreased stem girdling, sprout killing, stem canker, and black scurf prevalence among the three tested fungicides viz. mancozeb $75 \% \mathrm{WP}$, benlate and pencycuron. The present findings are in agreement with the results of Khanna et al., (1991) reported that Carbendazim was quite effective for managing black scurf of potato. Thind et al., (2002) reported that Carboxin 37.5+Thiram 37.5 WP was effective for reducing black scurf of potato than the Carboxin $75 \% \mathrm{WP}$ alone. At present study Carboxin 37.5+Thiram 37.5WS was also found effective for reducing the black scurf of potato. Thifluzamide $24 \%$ SC was less effective against sheath blight of rice in vitro study (Kaur and Singh, 2016) and it was also less effective in field experiment against sheath blight of rice (Hunjan et al., 2011). However, Kumar et al., (2012) reported that Thifluzamide $24 \%$ SC was found effective both as preventive and curative activity without any symptoms of phytotoxicity against sheath blight of rice. Difference in results, might be due to doses and time of applications. In the present investigation Thifluzamide $24 \%$ SC was found effective for managing black scurf of potato, by slurry seed treatment; because in this method whole tubers were fully covered by the chemicals, thereby less chance of survive the inoculums present at surface of potato tubers.

In conclusion, the results revealed that the Thifluzamide 24\% SC @ 2.0, 2.5 and 3.0 $\mathrm{ml} / 10 \mathrm{~kg}$ seed were found equally effective by slurry method against black scurf disease of potato and no phytotoxicity was observed at these doses.

\section{Acknowledgement}

Authors are grateful to $\mathrm{M} / \mathrm{s}$ Insecticide (India) Limited for giving opportunity to evaluate Thifluzamide 24\% SC against black scurf of potato. Authors are also grateful to Director ICAR-CPRI, Shimla and Joint Director ICAR-CPRIC, Modipuram for providing facilities during the experimentation.

\section{References}

Anonymous.1987. Sixteenth Progress Report. All India Coordinated Potato Projects, CPRI, Shimla, India, 69p.

Arora, R. K.2012. Eco-friendly management of soil and tuber borne diseases of potato. Indian Phytopatho, 65, 116-21.

Banville, G. J. 1989. Yield losses and damage to potato plants caused by Rhizoctonia Solani Kühn. Am. J. Potato Res., 66, 821-834.

Banyal, D. K.2002. Management of tuber borne diseases of potato. Pl. Dis. Res., 17, 323-324.

FRAC Code List.2017. Fungicides sorted by mode of action (including FRAC Code numbering).1-12. Www. farc.info

Hunjan, M.S., Lore J.S., Pannu P.P.S., Thind T.S. 2011. Performance of some new fungicides against sheath blight and brown spot of rice. Pl. Dis. Res., 26 (1):61-67.

Kaur, Tejdeep and Singh, Inderjeet.2016. Comparative evaluation of different fungicides against sheath blight of rice in vitro. Prog. Agric. 16 (2): 198-203.

Khanna, R.N., Roy, S., Roy, R.P., Sharma, J., Jeswani, M.D. and Singh, P.H. (1991). Annual Scientific Report. Central Potato Research Institute, Shimla, pp.74.

Khurana S M P, Pandey S K, Bhale R L, Patel B K and Lakra B S.1998. Surveillance for potato diseases in India over last five years. J. Indian Potato Assoc., 25, 16-20.

Khurana, S. M. P., Thind, T. S. and Mohan, C. 2001. Diseases of potato and their management, In Diseases of fruits and vegetables and their management. 
Thind TS (ed.) Kanlayani Publisher New Delhi: 237-265.

Kumar, M. K. Prasanna, D. K. Sidde Gowda, K. T. Pandurange Gowda and K. Vishwanath. 2012. A New Carboxynilide Group Fungicide against Paddy Sheath Blight. Res. J. of Agricultural Sciences, 3(2): 500-505.

Lakra, B. S. 1992. Correlation of infection intensities of black scurf with yield components of potato. Indian J. Mycol. Plant Pathol. 22, 203-204.

Lal, M., Sharma S, Yadav S and Kaushik S. K.2014. Bioefficacy of new molecule: penflufen 240 fs against black scurf of potato. Int J Agric Stat Sci., 10 (supplement 1), 63-66.

Lal, M., Yadav S. and Chand, S. 2016. Thiophanate methyl $45 \%+$ Pyraclostrobin 5\% FS: A new molecule for potato tubers treatment against black scurf disease of potato caused by Rhizoctonia solani. Indian $\mathrm{J}$ of Plant Prot.under review.

Rauf, C., Ahmad I., and Ashraf, M. 2007. Management of Black Scurf Disease of Potato. Pakistan J. of Botany, 39, 13411352.

Sharma, S. 2015. Black Scurf. In A manual on diseases and pest of potato-Tech Bull No. 101 (Ed. B.P. Singh, M. Nagesh,
Sanjeev Sharma, Vinay Sagar, A Jeevvlatha and J. Sridhar) ICARCentral Potato Research Institute, Shimla, HP, India, p. 11-13.

Singh, B. P., Arora R. K. and Khurana, S. M. P.2002. Soil and Tuber Borne Diseases of Potato. CPRI, Shimla, India, Tech Bull., 41, 74p.

Somani, A. K.1986. Non- hazardous chemical control of black scurf of potato. Indian J. Agric. Sci., 56, 366-369.

Somani, A. K.1988. Control of black scurf (Rhizoctonia Solani) and common scab (Streptomyces scabies) of potato (Solanum tuberosum) with boric acid. Indian J. Agric. Sci., 8, 693-698.

Thind, T.S., Mohan, Chander and Kaur, S. 2002. Promising activity of pencycuron, a phenylurea-based fungicide, for effective management of black scurf of potato. Indian Phytopath, 55 (1):39-44.

Tsror, L.2010. Biology, Epidemiology and Management of Rhizoctonia solani on potato. J. of Phytopathol, 158, 649-658.

Woodhall, J.W., Lees, A.K., Edwards, S.H. and Jenkinson, P. 2008. Infection of potato by Rhizoctonia solani: effect of anastomosis group. Plant Patholo, 57, 897-905.

http://www.cibrc.nic.in/mup.htm

\section{How to cite this article:}

Mehi Lal, Sanjeev Sharma, Chakrabarti S. K. and Manoj Kumar. 2017. Thifluzamide 24\% SC: A New Molecule for Potato Tubers Treatment against Black Scurf Disease of Potato Caused by Rhizoctonia solani. Int.J.Curr.Microbiol.App.Sci. 6(6): 370-375. doi: https://doi.org/10.20546/ijcmas.2017.606.043 